\title{
Cloak and Dagger in University Library Administration*
}

Mr. Milczewski is Assistant Librarian, University of California, Berkeley.

"C LOAK AND DAGGER in University Library Administration" better describes the contents of this paper than does "Guide Lines for University Policy and Action" as it appears in the program for this morning. The kinds of intelligence activities carried on by the Central Intelligence Agency, adjusted to the scope of activities of university libraries, are as proportionately necessary and productive for the latter as they are for national government.

Ideally, universities are so administered as to provide means of keeping the librarian informed of proposals which may result in educational policies and programs or changes in them well in advance of related demands for books and library services. Departure from the ideal, however, and secrecy of university administrations are so common that some means are usually found by most library administrators to supplement or to take the place of formal means of keeping the library informed and to circumvent university secrecy. Even in an ideal situation, dependence on formal statements of educational policy or announcements of new teaching or research programs is not enough. Such statements and announcements usually appear too late for the library to be ready by the time the instruction or research begins. The librarian and other members of the staff may hold

* Paper delivered on 1 I July 1951 , in Chicago, at the
general meeting of the University Libraries Section of general meeting of the University Libraries Section of the Association of College and Reference Libraries. membership on the legislative body of the faculty, educational policy committees or other academic or administrative committees. But these bodies at best consider programs too close to the time of putting them into effect. Local situations respecting the financing of universities and the uncertainties created by both the national and international situations make it all the more necessary for library administrators to throw on the cloak-even if girding on the dagger may not be necessary.

Librarians must find out in advance what they may be required to do before official notification is given them. In smaller universities the relationships between librarian, faculty and administration are so intimate as to provide an embarrassing amount of information. In larger universities the gothic walls between departments are thick and not provided with conduits for intercommunication systems and the grapevine is a not trustworthy replacement for more adequate means of communication. There are many means a librarian can use to get the information he needs. A few of the more common sources he can tap are described in the following paragraphs with some examples based on experience at Berkeley.

There is, of course, no more productive source than personal contact between the librarian and the faculty and administrative officers. A complementary source consists of similar relations between other members of the library staff and the library's clientele. Foretelling a future library activity 
may be the answer to a simple request for an opinion by the librarian from a faculty member on the possible need for developing a cooperative program of North African studies involving many disciplines. The place where such a request may have been made could be almost anywhere but, as often as not, is in the faculty club just before lunch. The librarian of the University of California at Berkeley uses this as an example of what he calls the "washroom theory of administration." It might, on the other hand, be a request to the librarian for an opinion by a faculty committee working out changes in program that will directly and immediately affect the library. This might be, for example, a proposal to substitute film copies for the typescript copies of theses now required for deposit in the library. (In this instance at California the incentive for appointing the committee came from the librarian.) Members of the library staff, particularly those in subject fields who have close faculty contacts, secure useful information. In the social sciences field, interdepartmental discussions about development in teaching and research in the field of industrial relations coming to the attention of the Social Sciences Reference Librarian at Berkeley prepare him to reorganize and extend the labor collection and furnish him with a tentative basis for a request for space for books and additional personnel for service, all before any formal request may be received by the library from the faculty. These will bring similar experiences to your minds.

Every faculty has more unrealized and unrealizable projects for improving the university's program of teaching and research than a university budget can comfortably accommodate. At some stage in their development they may reach typescript form or mimeographed to be given to a few members of the faculty for criticism before actual presentation to academic senate or university administration for support. These statements are hard to come by, especially in larger institutions, because neither the librarian nor his staff can have close enough relations with all faculty members and faculty groups to become automatic recipients of either the actual copies or of information about them. A copy of a statement of .present and proposed program of the Institute of East Asiatic Studies may be the first indication the library (and indeed the university administration) may have received that the scope of the Institute has broadened to Asiatic Studies and that the money needs are in the six figures instead of the four which have been customary. Books for the library and staff to give specialized service to the researchers are, of course, not provided for in the project statement. Forewarned by such a statement of intent; at least tentative plans can be considered for the library's not inconsiderable part in the venture.

A ten-year projection of the building needs of the Psychology Department at Berkeley includes as a space item quarters for a new psychology branch library. Assuming Psychology's space needs will be met, the library can begin to plan for a psychology branch library and to calculate how that will affect existing service to that department given by the University of California Biology Branch Library.

Student publications. The dailies and the monthly publications offer clues to what the university's policy may actually be on a disputed point or to future action. Feature articles on the work of academic departments or research projects may contain references to developments still in the "think" stage. Reports of interview with the president or other officers of the university may contain odd bits of information which may reveal the university's policy toward construction programs during the Korean crisis, for example. Plans for li- 
brary remodelling, long on the drawing boards, may rest there longer and intermediate plans may have to be put into effect.

The local press may reveal the plans local state congressmen may have in supporting a veterinary science department on another campus of the university. The effect on local book collections such a development in centralizing veterinary science on another campus may have can be established at least to some degree before the legislature appropriates a penny. The library on the campus recipient of the new program can be helped to assess its own pertinent holdings and to make plans for building up an appropriate collection.

There are many other sources, such as reports of the deliberations of legislative bodies, which may inform the librarian of what he may be expected to do sometime in the future. Discussions regarding the establishment of a legislative reference service for the legislature may result in action making unnecessary a library service given by the university to the legislature. Recommendations on limitations on enrollment and emphasis on graduate study at Berkeley in a report resulting from a study authorized by the legislature on "The Needs of California in Education" gives the library a basis for estimating what its relative services to graduate and undergraduate students should be in the not too distant future.

Gold, even in California, is sometimes found in unexpected places. The library administration has been conscious for some time that development of the general educational policy of the University of California College of Agriculture at Davis, California, only 40 miles from Berkeley, would mean a considerable change in the Berkeley campus agricultural activities. There had been no very specific advance information about the changes except rumor, notification of the immediate movement of the particu- lar activity from Berkeley, or conjecture. The house organ of the Pacific Gas and Electric Company, quoting the Dean of the College of Agriculture, saved the day at one point by giving a clearer indication of what was actually going to take place than anything that had been stated before or since. The Dean was quoted as saying, "One objective of the Davis expansion program is to transfer to that campus, as soon as possible, a large part of the resident instruction and research now carried on at Berkeley and eventually to complete the transfer. Another purpose is the ultimate removal of the Agricultural Extension Service from Berkeley to Davis. These plans will materially increase the size and importance of the Davis campus, it will make available much needed room for other activities on the Berkeley campus." Although no immediate prospects were indicated for the various moves, at least the library was able to look a little further ahead with more confidence than it had previously and to make certain decisions about an agricultural reference service and about its relation to small divisional libraries in the Department of Agriculture.

These bits of information, if not evaluated, might lead to wrong conclusions. The Strayer Report, accepted as a statement of the educational pattern to be followed in the State of California said about the School of Architecture on the Berkeley campus :

... it would seem that, to maintain the same ratio between number of architects and the number of population that existed in 1947 , will require the licensing and the entrance upon practice of about Ioo additional architects each year. The State Board of Architectural Examiners estimates that about 25 per cent of the architects licensed to practice in California are trained outside the state. This would mean that the State should, if these proportions continue to prevail, train annually approximately 75 new architects. . . . in 1947 the University of Southern Cali- 
fornia graduated 20 and the University of California at Berkeley graduated 29, a total of 49 . It is entirely probable that these figures do not represent the total capacity of these two institutions, but in any case it would seem more economical to expand the facilities of these two schools than to create another school of architecture in the State.

If the library had accepted this statement at its face value, it would be looking forward to some development in the Architecture Library on the basis of increased enrollment in the School of Architecture on the Berkeley campus. However, discussions with a new Dean of Architecture on the Berkeley campus indicated that while, indeed, there was a necessity for improvement and expansion of library services, it would not be on the basis of more students but rather a different kind of use by a smaller student body and a reorganized teaching staff.

There is, of course, no absolutely certain way of getting all the information needed, but some of the basic information necessary the University of California Library found has been codified in the Policy Anthology, A Collection of Statements on University of California Educational Policy, with Special Reference to Its Libraries. The introduction states:

One of the abiding problems of library planners is to find out where the enterprises of which their libraries are a part are going. The library of as vocal and articulate an enterprise as a university might be supposed to have an easy time in solving this problem. Because, however, few university officers have occasion to make what are intended as "policy statements," the job is less simple than it might seem.

How do you recognize an educational policy statement? No precise definition has been attempted but, as the work has proceeded, a rough working definition has developed. If a statement has been made by a responsible officer or by a publication which can be assumed to speak for the University; and if that statement describes objectives; and if, in addition, it can be assumed to be useful to the University's libraries in determining their courses of action, it has been accepted as a statement of policy. In general, statements of ways through which policy will be realized have been avoided in favor of "pure" policy statements. However, such implementing of policy as the announcement of building programs has been included because a building is often concrete evidence of policy acceptance. The new Veterinary-Medicine Building at Davis, for instance, may be taken to guarantee the concentration and eventual transfer of that subject from Berkeley to the Davis campus. Furthermore, a building often includes, or may be assumed to include some time, a branch library and this has obvious bearing on library planning. Another touchstone to policy statement, as used here, is the question: "What has been said that will help the libraries frame a long-range plan of development as to collection, staff, quarters, etc.?"1

The anthology was not intended to be comprehensive, exhaustive, or official. Sources for materials included in the anthology were proceedings of the University of California All-University Faculty Conferences held annually during the spring recess, the alumni magazine, the daily student paper, the Faculty Bulletin, the reports of the Library Council, agenda and supporting statements for the meetings of the northern section of the Academic Senate, and a report of a survey of the needs of California and higher education. The anthology has been useful. The rapid changes taking place in the university demand constant attention to keeping such an anthology up-to-date.

The intelligence activity which brings together these bits of information may be a simple matter compared with the detection and coordination of national or international information which also serves as guide lines to university library policy and action. Where, for example, does one find the evidence indicating that the university library should be building its Korean collec-

${ }^{1}$ UC Library Council, Donald Coney, secretary. 
tion because of national needs? Facts known locally are that the University may be unique in having on its staff a Korean language specialist or an economist whose primary interest is Korean, and that the university library has a respectable collection of Korean materials of wide variety. How does that affect the future development on the campus of contract program dealing with Korea which may be negotiated between the University and the Department of National Defense or the State Department, for example. How should the library determine that it will begin amplifying its collection of North African materials at a time when the university itself does not have a stated unified program involving that area of the world? What determines the need to add to the library staff someone to evaluate the collection of Indian materials and to develop a program of acquisition along specific lines the university is sure to have to follow? Answers to these questions are harder to find and once found harder to support in terms of specific statements which indicate that the University of California, for example, will be counted on to develop collections and research programs in these areas. Straws in the wind are reports of meetings of learned societies, of meetings of committees of the same societies, reports from the Department of State, Department of Defense and other federal agencies. Usually the only clue which the university library finds to the government agency thinking on the matter may be found in the Library of Congress Information Bulletin. What effect on the university library's program will the $L C$
Information Bulletin statement about the Navy Research section of the Library of Congress have? This might well lead to advance thought on what the library's program should be with regard to restricted government documents and what it might do if it were to enter into some sort of a future contractual arrangement with the Department of Defense or any other government agency having unpublished reports which it might distribute to cooperating libraries under certain specific and highly limiting circumstances.

Rather than to leave a possible erroneous impression that the individual bits and pieces of information which have been noted in the earlier part of this paper may themselves be sufficient as guide lines to university library policy and action, let me say that policy and action result from a great deal of discussion, study and deliberation. Information must be brought together, analyzed, before being used as a basis for determining what the library's policy and line of action may be both in general terms and in such specific terms as preparation of budget requests for pencils, periodicals, and people.

It all seems simple, doesn't it? It's like explaining a parlor trick: "All you have to do is just _-" The trouble is that it takes time and that it is a deliberate seeking of information. I hope that the next major survey of a university library will include a statement on this aspect of keeping the library informed as well as the formal means to which most such surveys generally refer.

\section{Suggestions as to Officers Wanted}

The Nominating Committee of the new A.C.R.L. Pure and Applied Science Section (formed by the merger of the Agricultural and Engineering sections last July) would appreciate suggestions as to officers to head this section. Communicate with $\mathrm{H}$. Dean Stallings, Librarian of North Dakota Agricultural College at Fargo (Chairman); Miss Mildred Benton, librarian at the Naval Research Laboratory, Washington 25, D.C.; or Ralph H. Phelps, director of Engineering Societies Library, 29 West 39th Street, New York 18, N.Y. 